\title{
Impact of Locally Available Thermal Insulation Structures on Space Heating Demand of High-altitude Rural Buildings: A Case Study of Kyrgyzstan

\author{
Kedar Mehta ${ }^{1}$, Mathias Ehrenwirth ${ }^{1}$, Christoph Trinkl' ${ }^{1}$, Wilfried Zörner ${ }^{1}$ and Rick Greenough ${ }^{2}$ \\ ${ }^{1}$ Institute of new Energy Systems, Technische Hochschule Ingolstadt (Germany) \\ 2 Institute of Energy and Sustainable Development, De Montfort University, Leicester (UK)
}

\begin{abstract}
Kyrgyzstan is a high-altitude mountainous country situated in a cold climatic zone. The age of the residential buildings, poor housing conditions and the absence of proper thermal insulation result in high heat demand and low thermal comfort in Kyrgyz houses. To maintain thermal comfort, the rural residents use traditional heating stoves to burn solid fuels during the winter months. Overconsumption of natural resources is mainly responsible for deforestation, as well as indoor and outdoor air pollution. Implementation of building thermal insulation is considered as one of the potential measures for energy conservation. In regards to this, the presented research proposes the various thermal insulation structures developed from the locally available natural materials. Further to this, it identifies the effectiveness of various thermal insulation structures on the annual space heating demand of a highaltitude single-family house located in rural Kyrgyzstan. The results show that the insulation parameter helps to save a considerable amount of space heating demand by up to $30 \%$ in the case of existing houses and up to $70 \%$ for newly built houses in rural Kyrgyzstan.
\end{abstract}

Keywords: Domestic space heating, energy efficiency, cold climate, high-altitude, thermal insulation

\section{Introduction}

The Kyrgyz Republic is a landlocked country located in northeastern Central Asia between two major mountain systems, the Tian Shan and the Pamir with a population of around 6.3 million (NSC, 2018). Approximately $94 \%$ of the Kyrgyz Republic's territory is located at altitudes higher than 1,000 meters and almost $40 \%$ at higher than 3,000 meters above sea level (NSC, 2018). Hence, the Kyrgyz climate is characterized as sharp continental with a long and harsh winter. The variety of average surface temperatures is directly related to the country's territorial arrangement and therefore it ranges from $10^{\circ} \mathrm{C}$ in the areas at an altitude lower than 1,000 meters to $-5^{\circ} \mathrm{C}$ in the areas at an altitude higher than 3,000 meters. Average low winter temperatures can reach below $-20^{\circ} \mathrm{C}$ in high elevations, while average summer high temperatures are in the high teens to low twenties across the country (USAID, 2018). On the other hand, the average annual temperature is around $2{ }^{\circ} \mathrm{C}$ for the entire country. Fig. 1 represents the map of Kyrgyzstan as well as the map of the country's Köppen climate classification.
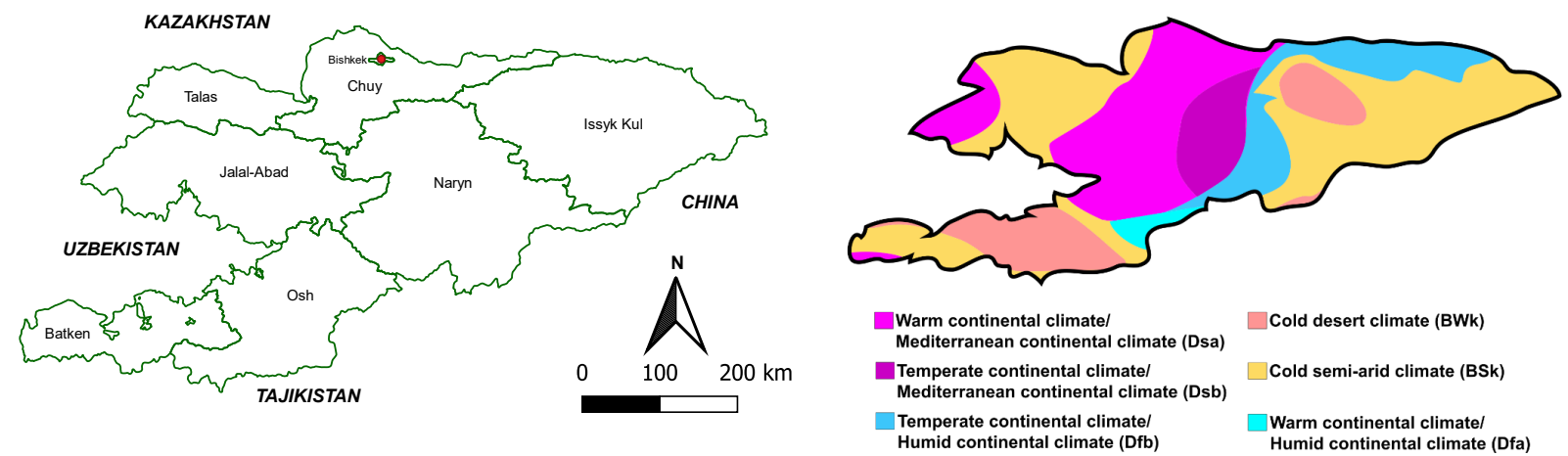

Fig. 1 Regional map of Kyrgyzstan (left) and its map of Köppen climate classification (right) (Köppen and Geiger, 2016)

The cold and extended winters in the country define house heating as a key primary need for Kyrgyz people. The buildings situated at high-altitude regions of Kyrgyzstan face a supplementary challenge because most of the energy is required for space heating rather than cooking. The higher the altitude, the longer and colder the winters will be and the more house heating is required (Wiedemann et al., 2012). Therefore, the residential sector is the highest energy-consuming sector in Kyrgyzstan (IEA, 2017). 
Almost all housing stock in Kyrgyzstan was constructed during the Soviet period roughly 35-60 years ago without proper construction materials, which leads to high heat demand, particularly in rural regions where almost $66 \%$ of the Kyrgyz population lives (UNICEF, 2013; NSC, 2018). While the connection to the district heating system is limited to the capital city and other urban areas, almost $80 \%$ of households resort to individual traditional heating solutions fueled by non-sustainable solid fuels (i.e. coal, firewood, wood branches, cow-dung etc.) (World Bank, 2020). To meet high heat demand and maintain thermal comfort in the house, rural people depend on the available natural resources. The existence of many uninsulated buildings, especially in rural Kyrgyzstan, has focused growing attention on the subject of building thermal insulation.

There is a need to identify suitable thermal insulation methods for residential buildings, particularly for high-altitude rural areas. Few researchers have addressed the problem and proved that the introduction of artificial insulation structures plays a vital role to reduce the space heating demand. However, by considering the local boundary conditions such as intense poverty and limited income of rural houses, the presented research article investigates the impact of insulation structures on Kyrgyz buildings, which are developed from the locally available sustainable insulation materials to make such insulation economically feasible.

\section{Profile of rural Kyrgyz buildings}

\subsection{An overview of traditional building structures}

Due to the mountainous nature of the Kyrgyz territory, less than $20 \%$ of the country is suitable for comfortable living. Therefore, most of the building stock (about $85 \%$ ) is concentrated in a comparatively small area as rural settlements, or urban clusters (UNFCC, 2017). The building traditions vary in different parts of Kyrgyzstan. Both residential and public buildings are characterized by low energy efficiency due to the age of the building stock, inadequate maintenance and the absence of proper thermal insulation. However, rural buildings in Kyrgyzstan are dominated by traditional construction techniques with conventional building materials such as earth, cob, adobe, stone and raw bricks. Most of the rural houses do not use construction materials with good insulating qualities for building construction (MEI, 2013). Further to this, building codes are not enforced adequately to rural households (UNECE, 2018).

The living space / floor area of the typical Kyrgyz house varies between $90 \mathrm{~m}^{2}$ to $110 \mathrm{~m}^{2}$ and is used by around four to five people on average. From a field visit to Ak-Tal (a high-altitude rural community situated in Naryn region), it was found that a typical rural house has an earthen floor with a layer of natural stone and / or concrete for the stability of the foundation as a first layer. The floor is built with a thickness of $0.25 \mathrm{~m}$ to $0.50 \mathrm{~m}$ usually without thermal insulation. The walls are commonly built with soil or adobe bricks with a thickness of $0.35 \mathrm{~m}$ to $0.50 \mathrm{~m}$ with no additional thermal insulation. However, the rural house walls are finished by a thin layer of lime plaster. Furthermore, the construction of a ceiling is similar to the floor, which consists of wooden boards and open space under the roof. The ceiling usually has a thin layer of clay-straw plaster to reduce the heat transfer through the ceiling. Rural buildings in Kyrgyzstan are generally built with wooden beam ceiling covered by a gable roof to protect the ceiling from the weather, especially snowfall and rainfall. Fig. 2 represents some typical traditional rural Kyrgyz houses.

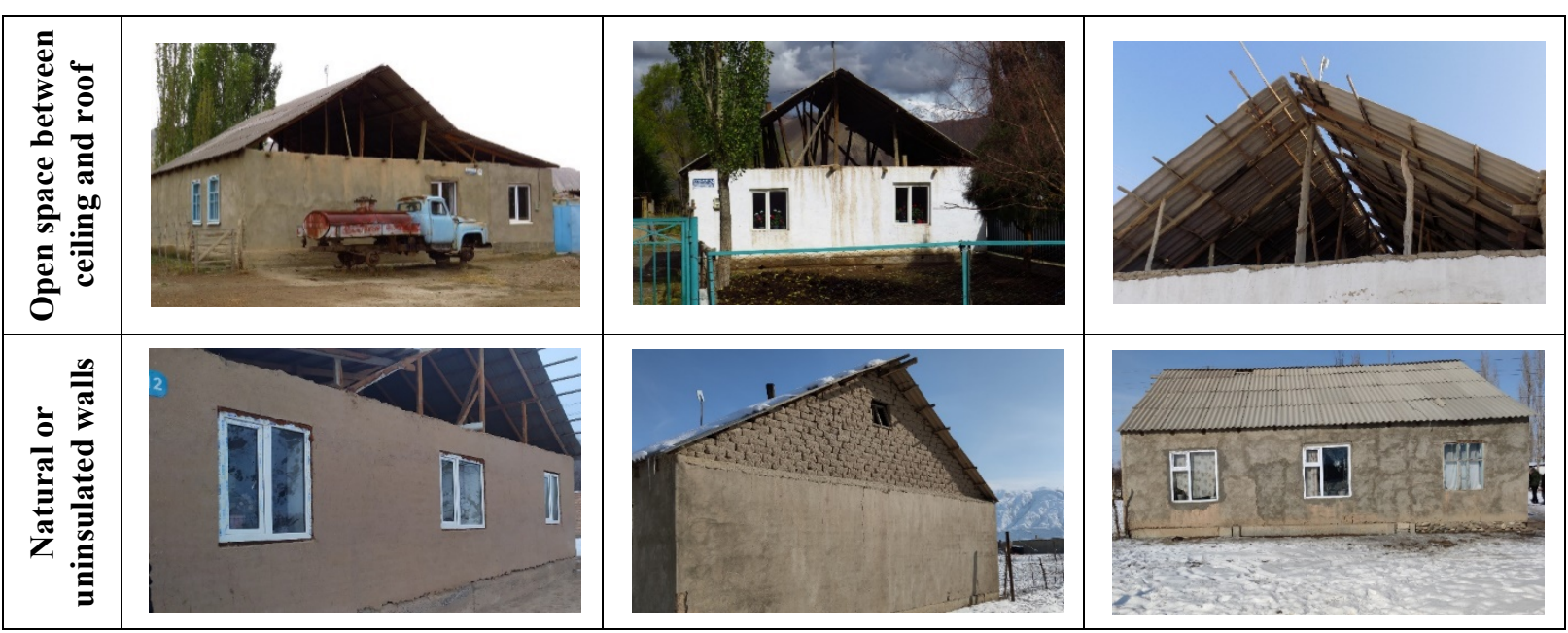

Fig. 2 Typical rural Kyrgyz houses in the Ak-Tal region 
Because of the inappropriate building structures, the energy consumption per square meter in Kyrgyzstan is almost 3-5 times higher compared to European countries (UNICEF, 2013). Kerimray et al. (2017) and Bergström and Johannessen (2014) also mentioned that the annual building energy consumption for heating in Kyrgyzstan (and other Central Asian countries) ranges between 240 and $360 \mathrm{kWh} / \mathrm{m}^{2}$, which is more than two times higher than the average European level. During winter, high-altitude regions need a considerable amount of energy, when the air temperature falls below zero during the heating period (October to March). The challenging climate patterns as well as traditional building structures are responsible for a high space heating demand in high-altitude rural settlements in Kyrgyzstan.

\subsection{Potential of energy savings in Kyrgyzstan}

The conditions of poor building infrastructure represent a huge potential for energy savings in Kyrgyzstan. According to the Mountain Societies Research Institute, up to almost $60 \%$ of heat losses can be saved by introducing the proper thermal insulation measures to rural buildings (Hall, 2018). Thermography is one of the most convenient ways to diagnose and monitor the heat transfer of a building. Hence, a thermographic analysis was performed in typical Kyrgyz households for the presented research work. The thermal images of some rural Kyrgyz houses are exemplarily shown in Fig. 3.
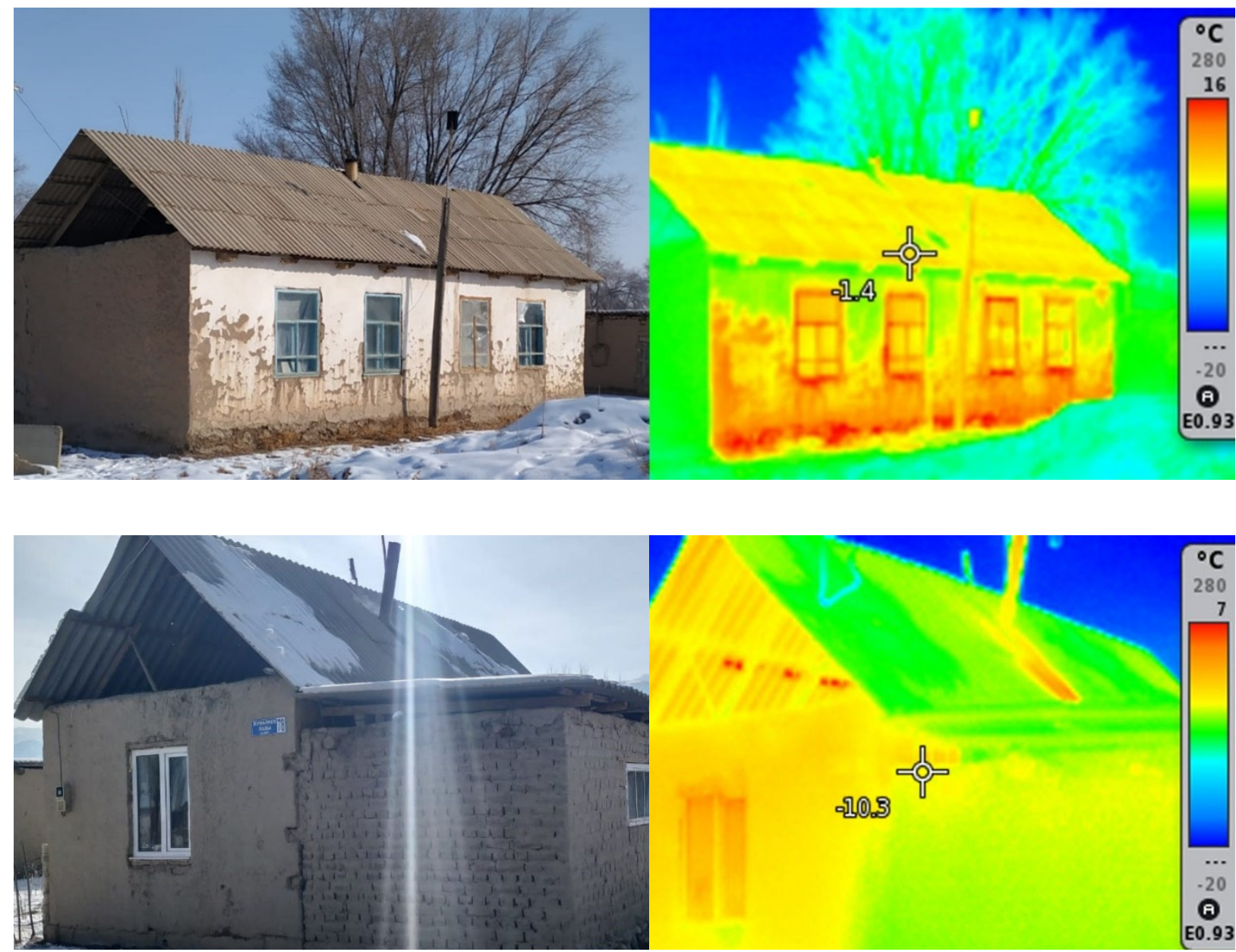

Fig. 3 Thermal images of uninsulated Kyrgyz houses in Ak-Tal region during the heating season

In the Kyrgyz Republic, access to reliable and affordable heating is mandatory because of the sharp and freezing winters. Because of the absence of heating solutions such as district heating in rural areas, nearly three-quarters of rural households use traditional stoves or boilers burning non-sustainable solid fuels to maintain thermal comfort in the house (Balabanyan, 2015; World Bank, 2020).

It was assessed from the on-site visit that during the winter period (from October to March), based on the availability of heating fuels and financial capabilities, the average rural family needs to use 2 to 4 tons of coal, 1.5 to $3 \mathrm{~m}^{3}$ of firewood and 1 to 2 truckloads of cow dung to maintain thermal comfort in the house. The high consumption of solid fuels promotes indoor and outdoor air pollution. Therefore, improving energy efficiency for rural houses is a vital factor in reducing the space heating demand. 


\section{Potential of natural insulation materials in Kyrgyzstan}

Kyrgyzstan's poverty level remains high with a Human Development Index (HDI) ranking of 122 out of 195 countries and $26.5 \%$ of the population living below the national poverty line (World Bank, 2016; UNDP, 2018). The village population is heavily dependent on the agriculture sector for their livelihood (FAO, 2016). The agriculture sector is the mainstay of the Kyrgyz economy and it covers $20 \%$ of the total GDP and engages $48 \%$ of the total human resources (FAO, 2016).

The land used for agricultural production accounts for almost $55 \%$ of Kyrgyz's total land area. The primary use of this land is for agriculture and pasture for livestock (mainly sheep, goats, and cattle), which is the traditional vocation of the Kyrgyz people. The active agriculture sector features a high number of livestock and the use of animal husbandry. Due to the specific geographical conditions of the country, most of the farms are located in mountainous regions at high altitudes. However, the cold climates and snowfall in the mountain regions slow down the agricultural activity during the winter in Kyrgyzstan. Agriculture is mostly reliant on climatic patterns and weather conditions as well as in most cases being vulnerable to environmental changes. Therefore, the rural population struggles to generate a constant income from their occupation in agriculture. This is one of the reasons for the higher poverty rate in rural Kyrgyzstan (Sagynbekova, 2017). Due to unstable income sources and intense poverty in rural Kyrgyzstan, the application of thermal insulation to their homes is not considered practical by most rural householders (Hall, 2018).

On the contrary, the active agricultural sector in combination with a considerable amount of livestock reveals a great potential of natural and sustainable materials, which can be utilized as thermal insulation for rural Kyrgyz houses. Furthermore, the geographical location of Kyrgyzstan allows the import of modern insulation materials from neighboring countries (i.e. China and Russia). Therefore, besides natural insulation materials, the assessment identified the availability and countable suppliers of modern insulation materials in Kyrgyzstan (KyrSEFF, 2018). Fig. 4 represents information on the classification of widely available insulation materials in Kyrgyzstan.

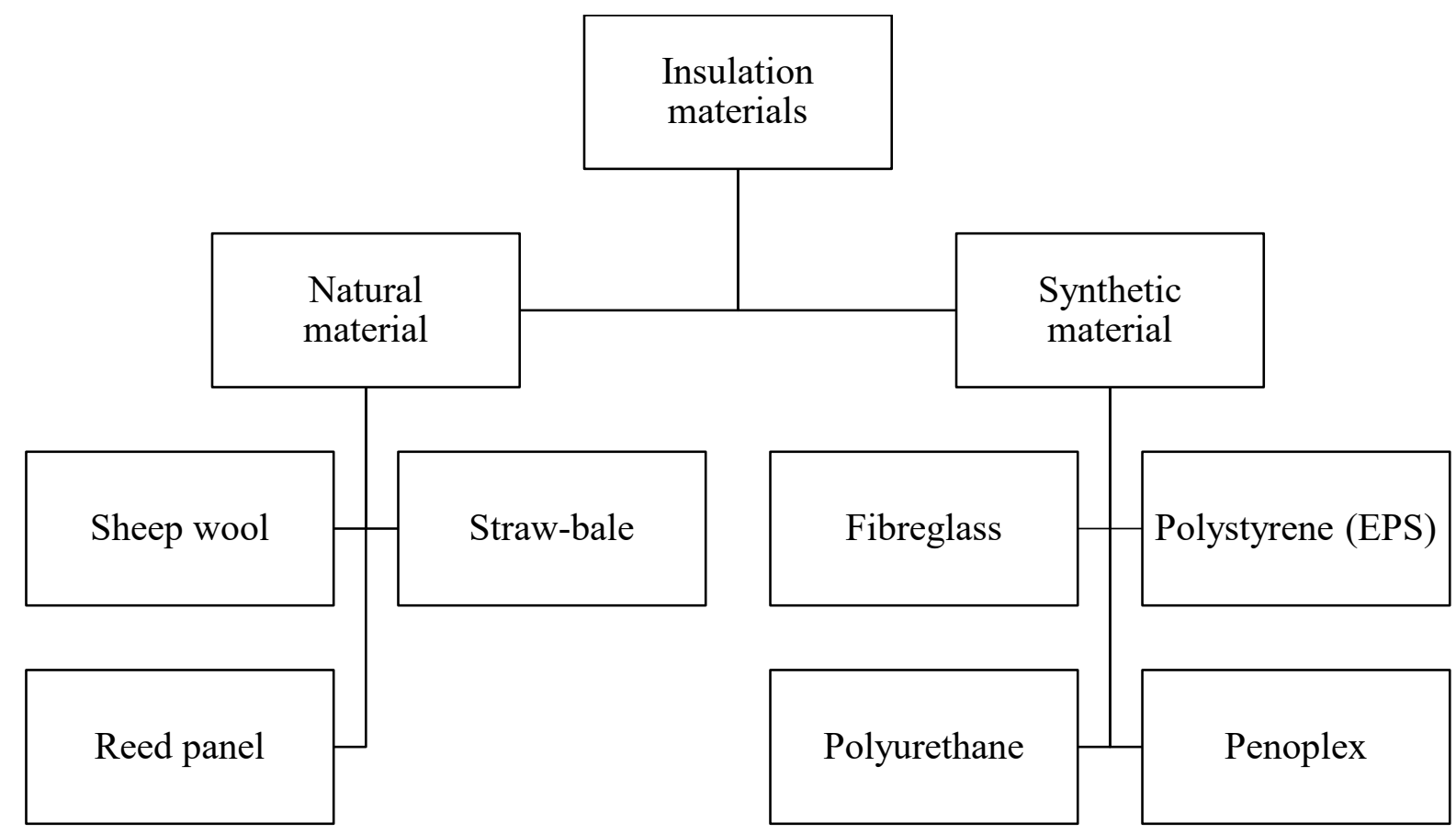

Fig. 4 Classification of widely available building insulation materials in Kyrgyzstan

The thermal properties of insulation materials as well as the minimum recommended thickness of natural and synthetic materials are mentioned by several institutes and organizations working in Kyrgyzstan to improve energy efficiency standards. The suggested values with the range of average thermal conductivity are mentioned in Tab. 1 . The use of specified materials is not widespread in Kyrgyzstan because of the lack of knowledge and limited income sources of rural people. 
Tab. 1 Comparative analysis of the thermal performance of natural insulation materials and synthetic materials (data according to CEEBA, 2011; Aditya et al., 2017; UNIDO, 2017; KyrSEFF, 2018; Polonets, 2019)

\begin{tabular}{|c|c|c|c|c|c|}
\hline \multirow{2}{*}{ Type } & \multirow{2}{*}{ Material } & \multirow{2}{*}{$\begin{array}{l}\text { Thermal conductivity in } \\
\qquad W /(\mathbf{m} \cdot \mathbf{K})\end{array}$} & \multicolumn{3}{|c|}{ Recommended minimum thickness in mm } \\
\hline & & & Walls & Floor & Roof \\
\hline \multirow{3}{*}{ 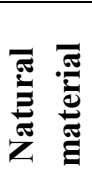 } & Sheep wool & $0.038-0.054$ & 60 & 60 & 100 \\
\hline & Straw-bale & $0.028-0.030$ & 40 & 40 & 100 \\
\hline & Reed panel & $0.055-0.070$ & 90 & 90 & 150 \\
\hline \multirow{4}{*}{ 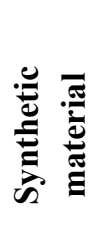 } & Fiberglass & $0.030-0.040$ & - & - & - \\
\hline & Polystyrene (EPS) & $0.038-0.042$ & 50 & 50 & 100 \\
\hline & Polyurethane & $0.021-0.038$ & 30 & 30 & 80 \\
\hline & Penoplex & 0.028 & 30 & 30 & 60 \\
\hline
\end{tabular}

\section{Comparative analysis of insulation structures on space heating demand}

\subsection{Application of thermal insulation in rural Kyrgyz houses}

The assessment identified that both natural and synthetic insulation materials are available in Kyrgyzstan. Synthetic materials are mainly available in urban areas but are not easily accessible in rural areas. Furthermore, synthetic materials (generally industry processed) are expensive and - due to the poverty of rural Kyrgyz people - not affordable for a typical villager. There is therefore an urgent need to develop affordable insulation methods based on natural resources, which are widely and locally available in rural Kyrgyzstan to reduce the over usage of nonsustainable solid fuels. Hence, this research article considers the natural insulation materials in Tab.1 to develop insulation methods and to assess their effectiveness in reducing the space heating demand.

In general practice, it is a strategic approach to insulate a building from main components, including walls, doors and windows, where heat transfer predominantly takes place (Aditya et al., 2017). However, traditional buildings in Kyrgyzstan have different characteristics, such as an open space between ceiling and roof, natural walls as well as an uninsulated or poorly insulated floor and ceiling. Therefore, this research article considers the typical vernacular architecture of Kyrgyzstan and different classified categories for insulation application as mentioned in Tab. 2 .

Tab. 2 Details of various cases of application of thermal insulation for investigation

\begin{tabular}{|c|c|c|c|}
\hline $\begin{array}{c}\text { Case studies for } \\
\text { investigation }\end{array}$ & $\begin{array}{c}\text { Case 1 } \\
\text { Closing of open roof from } \\
\text { both sides (roof cover) }\end{array}$ & $\begin{array}{c}\text { Insulation of existing } \\
\text { rural houses }\end{array}$ & $\begin{array}{c}\text { Insulation of new house } \\
\text { construction }\end{array}$ \\
\hline Roof cover & $\checkmark$ & - & - \\
\hline Wall insulation & - & $\checkmark$ & $\checkmark$ \\
\hline Floor insulation & - & - & $\checkmark$ \\
\hline Ceiling insulation & - & $\checkmark$ & $\checkmark$ \\
\hline
\end{tabular}

4.2 Development of simulation models and results for different cases

The investigation recommended the various thermal insulation approaches using the available sustainable materials and their effects on the overall thermal load of a rural house. To evaluate the impact of various insulation methods, a high-altitude single-family house, situated in rural Kyrgyzstan was modeled and its thermal load was calculated in EnergyPlus (NREL, 2019). The uninsulated house model was later modified by the application of thermal insulation methods to investigate the different cases mentioned in Tab. 2. To identify the influence of the thermal insulation, the improved heat demand of an insulated house was compared with the heat demand of an uninsulated house.

- Uninsulated house

The typical uninsulated rural Kyrgyz house was modelled in EnergyPlus based on the author's observations and interviews with rural Kyrgyz people living in the rural Naryn region. The selected single-family house was designed without any thermal insulation and provided $100 \mathrm{~m}^{2}$ of living area with a single thermal zone. The orientation of the 
house was assigned to the northern hemisphere. Two windows were considered, one in the eastern wall and one in the western wall, each with an area of $6 \mathrm{~m}^{2}$, in order to maximize solar gains. To achieve and maintain thermal comfort in the reference house, the heating set point of the house was considered to be $20^{\circ} \mathrm{C}$. The construction of the opaque elements (walls, floor, and ceiling) is described in Tab. 3.

Tab. 3 Assigned data set to EnergyPlus for construction of buildings elements

\begin{tabular}{|c|c|c|c|c|c|c|}
\hline Assembly & Layer & $\begin{array}{c}\text { Thickness } \\
\text { [m] }\end{array}$ & $\begin{array}{c}\text { Conductivity } \\
{[\mathrm{W} /(\mathrm{mK})]}\end{array}$ & $\begin{array}{l}\text { Density } \\
{\left[\mathrm{kg} / \mathrm{m}^{3}\right]}\end{array}$ & $\begin{array}{c}\text { Capacity } \\
{[\mathrm{kJ} /(\mathrm{kgK})]}\end{array}$ & $\begin{array}{c}\text { U-value } \\
{\left[\mathbf{W} /\left(\mathbf{m}^{2} \mathbf{K}\right)\right]}\end{array}$ \\
\hline \multirow{2}{*}{$\begin{array}{l}\text { Wooden beam } \\
\text { ceiling with } \\
\text { gable roof }\end{array}$} & Clay-straw mixture & 0.03 & 0.10 & 300 & 0.90 & \multirow{2}{*}{0.86} \\
\hline & Spruce wood & 0.08 & 0.13 & 450 & 1,60 & \\
\hline \multirow{3}{*}{ External walls } & Lime render & 0.02 & 0.87 & 1,400 & 1.00 & \multirow{3}{*}{1.13} \\
\hline & Adobe brick & 0.40 & 0.58 & 1,600 & 0.84 & \\
\hline & Lime render & 0.02 & 0.87 & 1,400 & 1.00 & \\
\hline \multirow{2}{*}{ Floor } & Spruce wood & 0.05 & 0.13 & 450 & 1.60 & \multirow{2}{*}{1.48} \\
\hline & Concrete slab & 0.25 & 2.00 & 2,400 & 0.95 & \\
\hline \multirow{3}{*}{ Window } & Glass & 0.006 & 0.90 & - & - & \multirow{3}{*}{3.6} \\
\hline & Air & 0.003 & - & - & - & \\
\hline & Glass & 0.006 & 0.90 & - & - & \\
\hline
\end{tabular}

The heat demand of the reference house was calculated in EnergyPlus by considering the heat losses through different building components (i.e. walls, floor and ceiling), local climate, occupant's behavior, internal gains, external solar gains etc. To simulate the open roof space in EnergyPlus, the reference house with an open roof space was developed as a rectangular-shaped single node model, where the exterior ceiling which was not exposed to solar irradiation but to convection by the wind. Fig. 5 represents the obtained monthly space heating demand of the specified reference house with the monthly average temperature. The annual specific heat demand of single-family houses in rural Kyrgyzstan for space heating is $302 \mathrm{kWh} / \mathrm{m}^{2}$ which is validated with the available literature (Bergström and Johannessen, 2014; Kerimray et al., 2017).

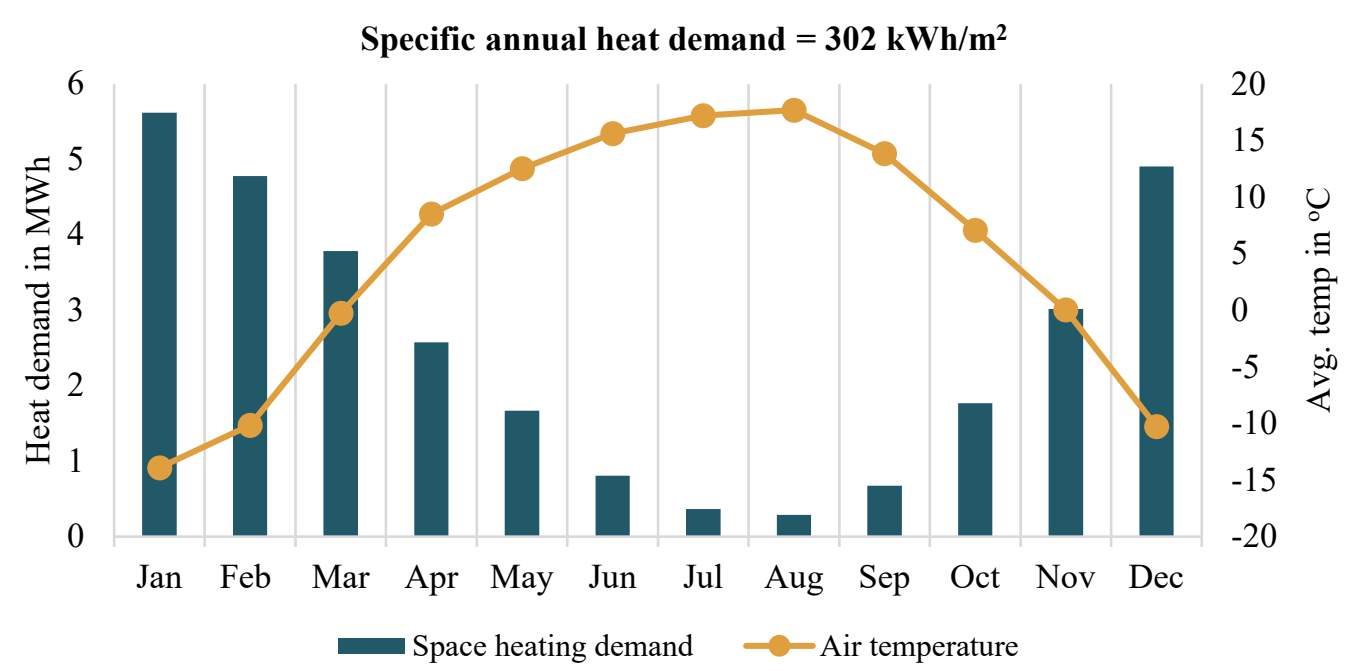

Fig. 5 Monthly space heating demand of reference (uninsulated) building and average ambient temperature of location

- Case 1: Closing of open roof from both sides (roof cover)

In the older and cheaply constructed houses, the metal roof is placed on the wooden beam ceiling. However, because of the concentrated poverty in rural areas and traditional building construction methods, the gable roof usually is not covered at either end, which creates an open space between the ceiling and gable roof (see Fig. 2). This is a prevalent practice for low-income Kyrgyz households. Naturally, the open space induces a considerable amount of heat loss during windy days. The closing of the open roof of typical buildings can be helpful to reduce the thermal load of the house. Therefore, in the presented article, this case was considered as case 1 by covering the roof to investigate its impact on the thermal load of the reference building. 
To investigate case 1 , the open roof of an uninsulated house was covered with a thick layer of spruce wood $(0.05 \mathrm{~m})$ from both sides in order to prevent air leakage through the uncovered space between the ceiling and roof. This case was modelled without any additional application of insulation materials. The result of case 1 is presented in Tab. 4, which outlines the heat demand comparison of the reference uninsulated house with an open and a closed roof.

Tab. 4 Comparison of specific annual heat demand for case 1

\begin{tabular}{|l|l|l|l|}
\hline \multicolumn{2}{|c|}{ Uninsulated house with open roof } & Uninsulated house with closed roof \\
\hline Specific annual heat demand $=302 \mathrm{kWh} / \mathrm{m}^{2}$ & Specific annual heat demand $=243 \mathrm{kWh} / \mathrm{m}^{2}$ \\
\hline
\end{tabular}

- Case 2: Insulation of existing rural houses

A potential way to improve energy efficiency standards of the existing traditional rural buildings will be to apply insulation layers on the exterior walls as well as on ceiling. Therefore, for case 2, an existing house was modelled and simulated by the application of different insulation structures on walls and ceiling.

- Case 3: Insulation of new house construction

This case was designed and investigated for considering a new house under construction where the opportunity is available to insulate building walls, floor and ceiling. The selected house was insulated with natural insulation materials on the walls, floor and ceiling. The schematic of insulation structures for case 2 and case 3 is shown in Tab. 5.

Tab. 5 Schematic of insulation structures with the different natural insulation materials for walls, ceiling and floor

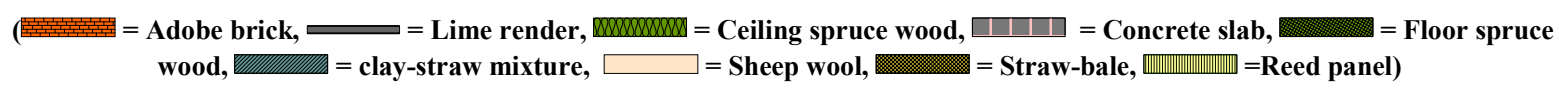

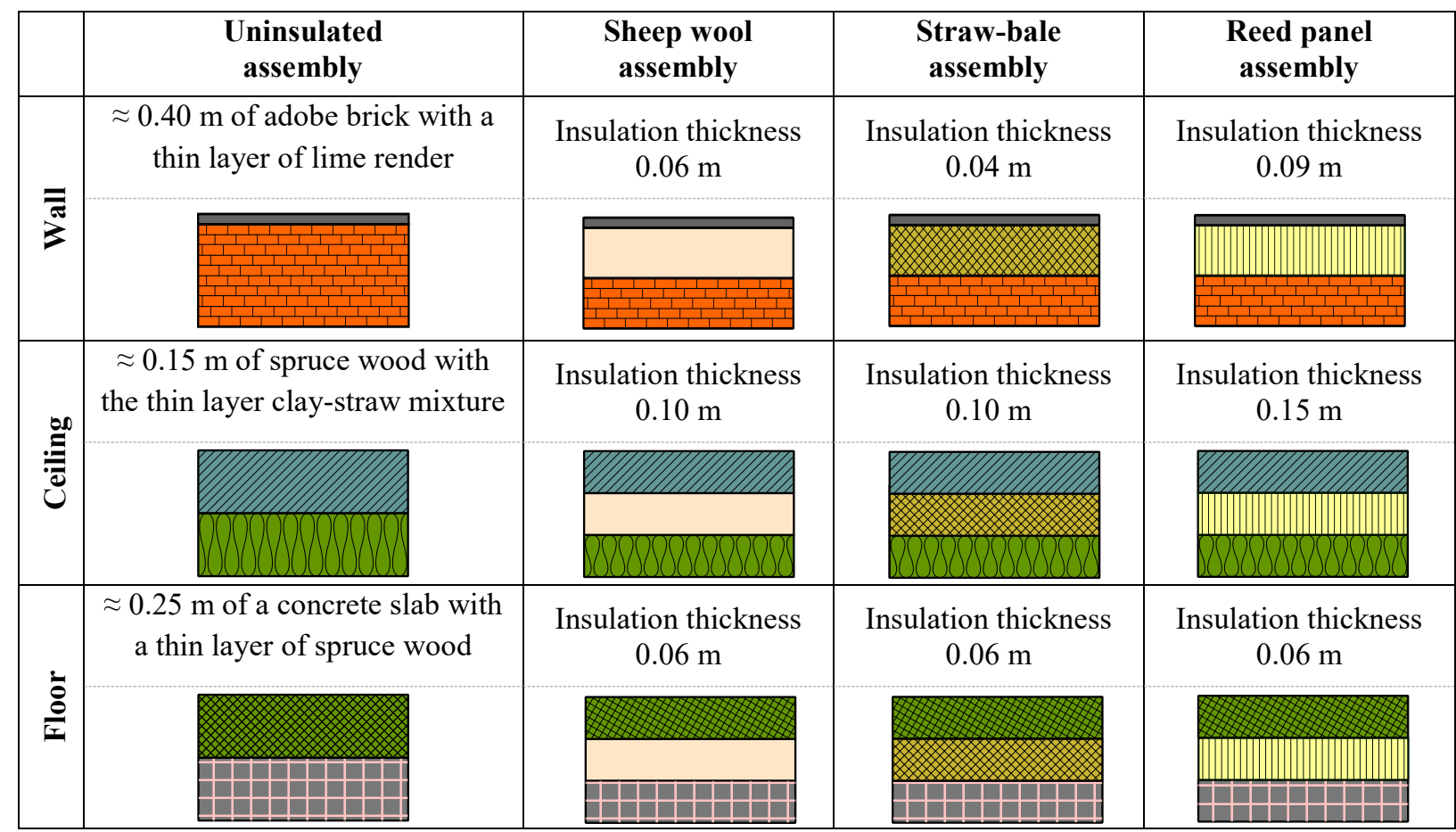

The results of thermal insulation and its impact on space heating demand were compared with the space heating demand of a traditional rural house (uninsulated) to outline the influence of insulation measures. The results of case 2 and case 3 are presented in Tab. 6 and Tab. 7 respectively. 
Tab. 6 Effectiveness of various insulation structures on space heating demand (case 2: Insulation of existing rural houses)

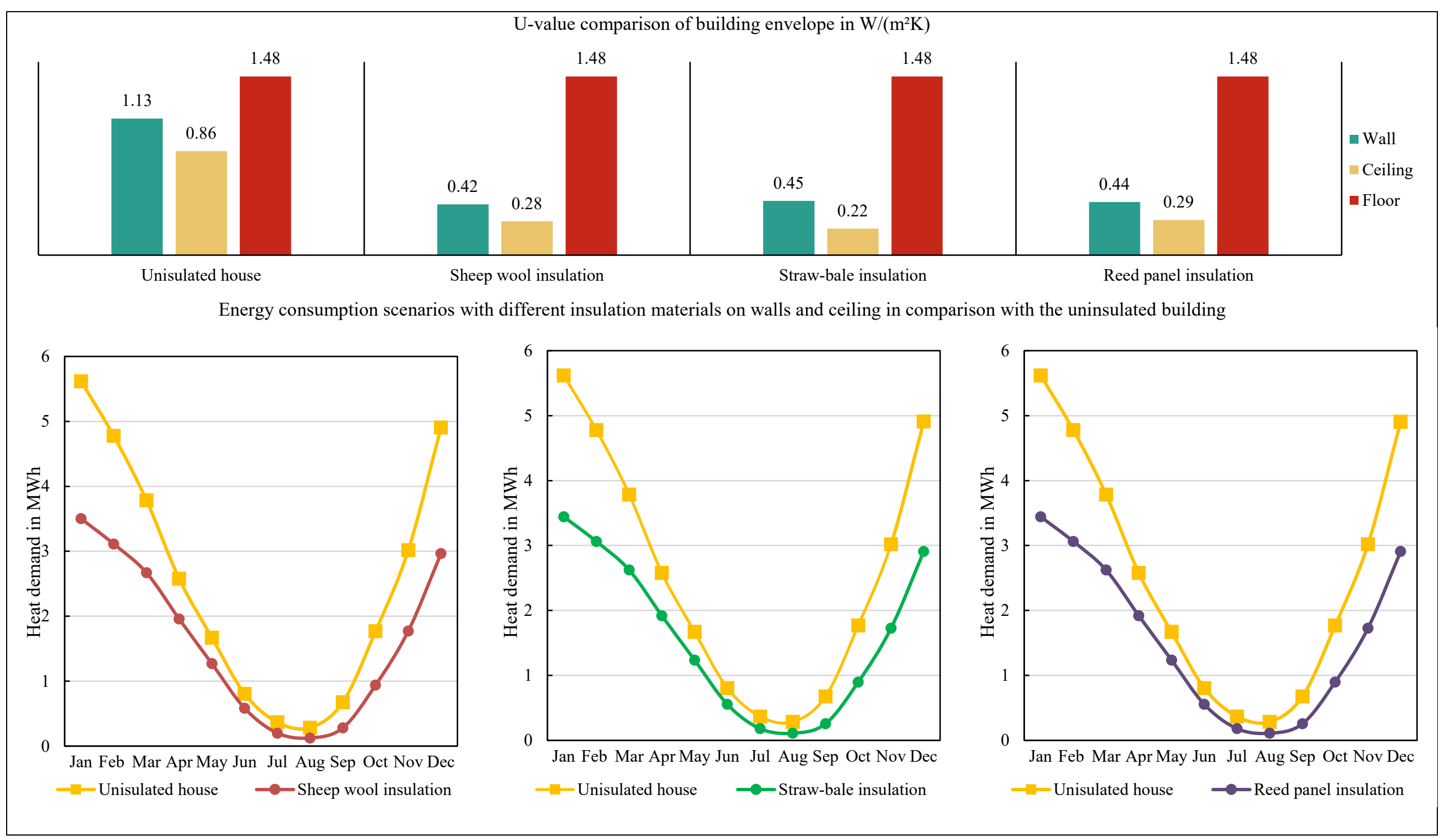


Tab. 7 Effectiveness of various insulation structures on space heating demand (case 3: Insulation of new house construction)

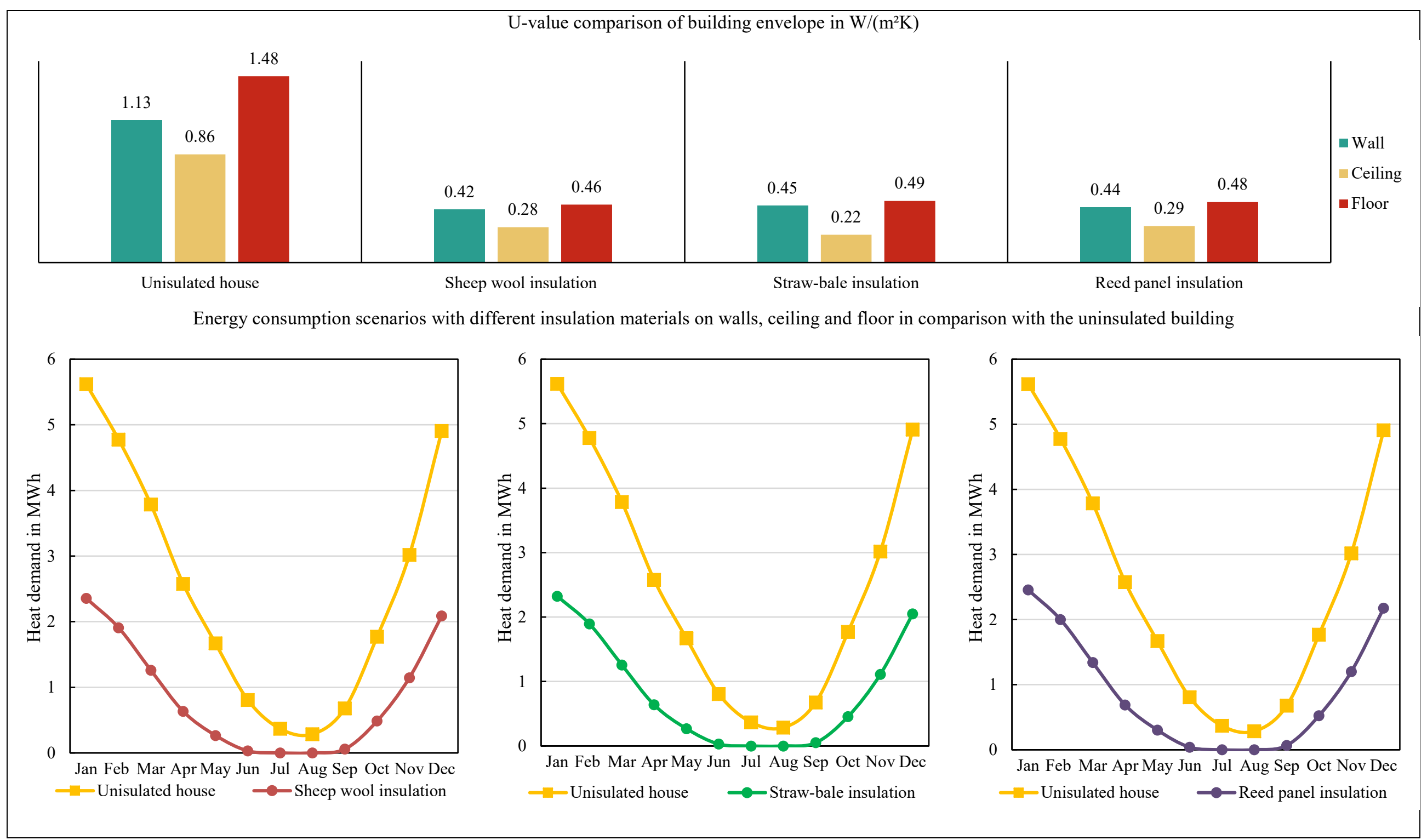


To summaries the effectiveness of different design concepts, the specific annual heat demand of various cases is presented in Tab. 8.

Tab. 8 Summary of results of comparative analysis of insulation structures on space heating demand

\begin{tabular}{|c|c|c|c|c|c|}
\hline \multirow{2}{*}{ Insulation type } & \multicolumn{4}{|c|}{ Insulation condition } & \multirow{2}{*}{$\begin{array}{l}\text { Specific annual heat } \\
\text { demand in } \mathrm{kWh} / \mathrm{m}^{2}\end{array}$} \\
\hline & Roof cover & Walls & Ceiling & Floor & \\
\hline \multirow{2}{*}{ Uninsulated house } & - & - & - & - & 302 \\
\hline & $\checkmark$ & - & - & - & 243 \\
\hline \multirow{2}{*}{ Sheep wool insulation } & - & $\checkmark$ & $\checkmark$ & - & 193 \\
\hline & - & $\checkmark$ & $\checkmark$ & $\checkmark$ & 102 \\
\hline \multirow{2}{*}{ Straw-bale insulation } & 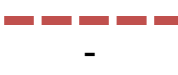 & $\checkmark$ & $\checkmark$ & - & 189 \\
\hline & - & $\checkmark$ & $\checkmark$ & $\checkmark$ & 100 \\
\hline \multirow{2}{*}{ Reed panel insulation } & -2 & $\checkmark$ & $\checkmark$ & - & 197 \\
\hline & - & $\checkmark$ & $\checkmark$ & $\checkmark$ & 107 \\
\hline
\end{tabular}

It can be observed from the results that depending on the insulation type in combination with insulation parameters, a considerable amount of heat demand can be reduced while maintaining comfort levels. The investigation identified that covering the open sides of the roof raises the opportunity to decrease the specific heat demand by up to $20 \%$. The insulation application to walls and ceiling can save up to $100 \mathrm{kWh} /$ year of heat demand in existing vernacular Kyrgyz buildings. Furthermore, the consideration of good insulation layers to walls, ceiling and floor (in case of new building construction) means that about $200 \mathrm{kWh} /$ year of thermal energy can be reduced per square meter. It can be seen from Tab. 8 that the straw-bale insulation structures have a substantially better effect on reducing space heating demand than other methods.

The natural materials mentioned in the study are locally available. Existing low-income rural households can adopt the presented idea to insulate their houses to reduce the space heating demand. Naturally, the reduction of thermal load can substantially reduce their heating fuel expenditure. The proposed investigation also suggested the sequence to insulate rural Kyrgyz house from derived results. Application of insulation layers to walls and ceiling can make a significant influence on heat demand and heating costs can be reduced by 10 to $30 \%$ according to house size and building construction quality. Also, according to future financial capability, one can introduce roof cover to the insulated house to reduce the heat leakages from open space, which can help to cut down the heating expenses up to 40 to $50 \%$.

\section{Conclusions}

The cold climate and high-altitude characteristics of Kyrgyzstan are experienced as a long and harsh winter period. The old and traditional buildings without any thermal insulation aggravate the high space heating demand in Kyrgyz houses, especially in rural regions. This high thermal demand of the house is principally met by the considerable use of non-sustainable solid fuels. The overuse of solid fuels, especially their combustion in inefficient traditional heating stoves exposes rural Kyrgyz people to indoor and outdoor air pollution. Appropriate thermal insulation is necessary to reduce the high space heating demand in rural Kyrgyzstan. However, because of the widespread and deep poverty as well as the lack of awareness in rural Kyrgyzstan, insulation measures are seldomly considered during building construction. Therefore, the presented research article has considered locally available natural and sustainable materials for the investigation, to make the insulation structures economically feasible.

Three widely available natural insulation materials of sheep wool, straw-bale and reed panel were chosen to design insulation structures. Various case studies were performed by considering local boundary conditions to conduct the investigation. The results of the assessment highlighted that the thermal insulation measures can substantially reduce the heat demand by up to $30 \%$ in the case of existing houses and up to $70 \%$ for new houses in rural Kyrgyzstan, which will help to reduce a considerable amount of non-sustainable solid fuel use. The presented study was performed by considering the minimum recommended thickness suggested by local organizations. One can perform the study to identify the optimum level of thickness and feasibility study from the economic point of view. 


\section{Acknowledgments}

The work presented in this paper was funded by the Federal Ministry of Education and Research (BMBF) of the Federal Republic of Germany within the CLIENT II funding programme International Partnerships for Sustainable Innovations under the project "ÖkoFlussPlan" (Project ID 01LZ1802A-F). The overall aim of ÖkoFlussPlan is to preserve the alluvial forests along the Naryn river and to implement sustainable energy solutions for the local population.

\section{References}

Aditya, L., Mahlia, T.M.I., Rismanchi, B., Ng, H.M., Hasan, M.H., Metselaar, H.S.C., Muraza, O., Aditiya, H.B., 2017. A review on insulation materials for energy conservation in buildings. Renewable and Sustainable Energy Reviews 73, 1352-1365.

Balabanyan, A., 2015. Keeping warm: Urban heating options in the Kyrgyz Republic. Summary report (English). The World Bank Group, Washington, DC.

http://documents.worldbank.org/curated/en/555021468011161504/pdf/97409-WP-P133058-Box391503B-

PUBLIC-Heating-Assessment-for-Kyrgyz-P133058-Final.pdf. Accessed 27 April 2020.

Bergström, S., Johannessen, F., 2014. Sustainable housing in Kyrgyzstan. Investigation of two multi- apartment buildings in Bishkek. The Department of Energy Sciences. Lund University, Faculty of Engineering, Lund. http://www.ees.energy.lth.se/fileadmin/ees/Publikationer/Ex5297-Bergstrom_Johannessen.pdf. Accessed 18 February 2020.

FAO, 2016. National gender profile of agricultural and rural livelihoods - Kyrgyz Republic. Country gender assessment series. Food and Agriculture Organization of the United Nations, Ankara (Turkey). http://www.fao.org/3/a-i5763e.pdf. Accessed 20 July 2020.

Hall, K., 2018. Supporting energy efficiency and renewables uptake in rural communities in mountainous Kyrgyzstan. Mountain Societies Research Institute, Bishkek (Kyrgyzstan).

IEA, 2017. Total primary energy supply (TPES) by source. https://www.iea.org/data-andstatistics?country=KYRGYZSTAN\&fuel=Energy\%20supply\&indicator=Total $\% 20$ primary $\% 20$ energy\%20supply $\% 20$ (TPES)\%20by\%20source.

Kerimray, A., Miglio, R.D., Solorzano, L.R., Gallachóir, B.Ó., 2017. Household Energy Consumption and Energy Poverty in Kazakhstan IAEE Energy Forum 26, 31-34.

Köppen, Geiger, 2016. Kyrgyzstan map of Köppen climate classification. https://commons.wikimedia.org/wiki/File:Kyrgyzstan_map_of_K\%C3\%B6ppen_climate_classification.svg.

KyrSEFF, 2018. РУКОВОДСТВО для монтажников. Sustainable Energy Fund of Kyrgyzstan, Bishkek (Kyrgyzstan).

MEI, 2013. Microfinancing household insulation and heating measures in Kyrgyzstan. An Assessment Study by MicroEnergy International for Deutsche Gesellschaft für Internationale Zusammenarbeit GmbH. MicroEnergy International, Berlin (Germany). https://eba.klink.asia/klink/ccf9ca/download. Accessed 25 January 2019.

NREL, 2019. EnergyPlus. U.S. Department of Energy.

NSC, 2018. National Statistical Committee of the Kyrgyz Republic. Kyrgyzstan. Brief statistical handbook. Annual publication, Bishkek (Kyrgyzstan). http://www.stat.kg/media/publicationarchive/16db2910-6b8d-48f9-80b945b7ac3347bd.pdf. Accessed 10 August 2020.

Polonets, L., 2019. РУКОВОДСТВО для монтажников. Energy Centre Bratislava and CAMP Alatoo, Bratislava (Slovakia).

Sagynbekova, L., 2017. Environment, Rural Livelihoods, and Labor Migration. A Case Study in Central Kyrgyzstan. Mountain Research and Development 37 (4), 456-463.

UNDP, 2018. Latest Human Development Index (HDI) ranking. http://hdr.undp.org/en/2018-update. Accessed 24 February 2020.

UNECE, 2018. Mapping of Existing Energy Efficiency Standards and Technologies in Buildings in the UNECE Region, Geneva (Switzerland). https://www.unece.org/fileadmin/DAM/hlm/Meetings/2018/09_05- 
07_St._Petersburg/EE_Standards_in_Buildings_full_version.ENG.pdf.

UNFCC, 2017. Third National Communication of the Kyrgyz Republic under the UN Framework Convention on Climate Change, Bishkek (Kyrgyzstan).

https://unfccc.int/sites/default/files/resource/NC3_Kyrgyzstan_English_24Jan2017.pdf.

UNICEF, 2013. Improving Energy Efficiency in Buildings. United Nations Development Programme.

https:/www.kg.undp.org/content/kyrgyzstan/en/home/operations/projects/sustainable_development/energyefficiency-buildings.html.

UNIDO, 2017. Thermal Insulation. Propoerties and apllications in housing. United Nations Industrial Development Organization, Vienna (Austria).

USAID, 2018. Climate risk profile. Kyrgyz Republic.

https://www.climatelinks.org/sites/default/files/asset/document/2018_USAID-CCIS-Project_Climate-Risk-ProfileKyrgyz-Republic.pdf.pdf.

Wiedemann, C., Salzmann, S., Mirshakarov, I., Volkmer, H., 2012. Thermal Insulation in High Mountainous Regions. Mountain Research and Development 32 (3), 294-303.

World Bank, 2016. Kyrgyzstan: Poverty headcount ratio at national poverty lines (\% of population). https://data.worldbank.org/indicator/SI.POV.NAHC?locations=KG. Accessed 15 August 2020.

World Bank, 2020. Fueling Kyrgyzstan's Transition to Clean Household Heating Solutions. The World Bank Group, Washington, DC. 